DOI : https://doi.org/10.24843/JFU.2020.v09.i01.p08

pISSN: 2301-7716; eISSN: 2622-4607

Jurnal Farmasi Udayana, Vol 9, No 1, Tahun 2020, 52-61

\title{
Aktivitas Antibakteri Ekstrak Etanol Daun Kapas (Gossypium barbadense L.) terhadap Staphylococcus epidermidis dan Propionibacterium acnes
}

\author{
Antibacterial Activity of Ethanol Extract of Gossypium barbadense L. Leaves against Staphylococcus \\ epidermidis and Propionibacterium acnes
}

Arsa Wahyu Nugrahani ${ }^{*}$, Febriani Gunawan, Akhmad Khumaidi

Jurusan Farmasi, FMIPA Universitas Tadulako, Palu-Indonesia, 94118

*Email : arsa_wahyu@yahoo.com

Riwayat artikel: Dikirim: 27/02/2020; Diterima: 15/06/2020, Diterbitkan: 25/06/2020

\begin{abstract}
Gossypium barbadense L. is one of the plants that have the potential to be developed into an antibacterial agent. This study aims to determine the antibacterial activity of chemical compounds in ethanol extract of Gossypium barbadense L. leaves against Staphylococcus epidermidis and Propionibacterium acnes bacteria which are characterized by the formation of inhibitory zones. Extraction of Gossypium barbadense L. leaves was carried out by maceration using ethanol $96 \%$. Antibacterial activity testing was carried out by agar diffusion method with a cylinder plate technique and the extract was made a concentration series. TLC bioautography and chromogenic reagents are used in the identification of the secondary metabolites that have antibacterial activity. The results showed that the ethanol extract of Gossypium barbadense L. leaves gave the greatest inhibition at 50\% extract concentration with a diameter of $12.28 \pm 0.63 \mathrm{~mm}$ against Staphylococcus epidermidis and 70\% extract concentration against Propionibacterium acnes bacteria with a diameter of $11.40 \pm 032 \mathrm{~mm}$. Flavonoids are the secondary metabolites compounds to be responsible for antibacterial activity.
\end{abstract}

Keywords: Antibacterial, Gossypium barbadense L. Leaves, Propionibacterium acnes, Staphylococcus epidermidis

\section{ABSTRAK}

Kapas (Gossypium barbadense L.) merupakan salah satu tanaman yang berpotensi dapat dikembangkan menjadi agen antibakteri. Penelitian ini bertujuan untuk mengetahui kemampuan antibakteri senyawa kimia di dalam ekstrak etanol daun kapas terhadap bakteri Staphylococcus epidermidis dan Propionibacterium acnes yang ditandai dengan terbentuknya zona hambat. Ekstraksi daun kapas dilakukan secara maserasi menggunakan etanol 96\%. Pengujian aktivitas antibakteri dilakukan dengan metode difusi agar dengan teknik sumuran dan ekstrak uji dibuat seri konsentrasi. Kromatografi lapis tipis (KLT) bioautografi dan pereaksi kromogenik digunakan dalam identifikasi golongan senyawa yang mempunyai aktivitas antibakteri. Hasil penelitian menunjukkan bahwa ekstrak etanol daun kapas dengan konsentrasi 50\% memberikan daya hambat terbesar terhadap Staphylococcus epidermidis dengan diameter 12,28 $\pm 0,63 \mathrm{~mm}$ sedangkan ekstrak etanol 70\% memberikan aktivitas terbesar terhadap Propionibacterium acnes dengan diameter $11,40 \pm 0,32 \mathrm{~mm}$. Golongan senyawa yang diduga bertanggung jawab terhadap aktivitas antibakteri yaitu golongan flavonoid.

Kata kunci: $\quad$ Antibakteri, Daun Kapas (Gossypium barbadense L.), Propionibacterium acnes, Staphylococcus epidermidis

\section{PENDAHULUAN}

Kapas (Gossypium barbadense L.) adalah salah satu tanaman yang berpotensi sebagai agen antibakteri. Secara empiris, tanaman kapas digunakan sebagai obat jerawat [1]. Ekstrak daun kapas dan minyak esensialnya memiliki potensi antimikroba pada beberapa mikroorganisme [2,3]. Hasil penelitian dari spesies yang berbeda
(Gossypium arboreum L.) diketahui bahwa ekstrak etanol daun kapas memiliki aktivitas antibakteri [4]. Selain itu, ekstrak air daun kapas memiliki aktivitas sebagai penyembuh luka [5]. Informasi penggunaan daun kapas sebagai obat luka menimbulkan dugaan bahwa daun kapas mengandung senyawa yang dapat membunuh bakteri (antibakteri). 
DOI : https://doi.org/10.24843/JFU.2020.v09.i01.p08

pISSN: 2301-7716; eISSN: 2622-4607

Jurnal Farmasi Udayana, Vol 9, No 1, Tahun 2020, 53-62

Daun kapas memiliki kandungan kimia bioaktif seperti flavonoid, fenolik, alkaloid, glikosida, dan saponin [6]. Selain itu, daun kapas juga memiliki senyawa triterpenoid dan seskuiterpenoid. Terdapat sembilan belas komponen kimia dari 92,6\% total fraksi minyak esensial daun kapas. Kandungan kimia dari ekstrak daun kapas tersebut antara lain tricyclene $(29,6 \%)$, bornyl acetate $(18,6 \%)$, a-pinene $(12,8 \%)$, a-terpinene $(11,1 \%)$, isoledene $(6,0 \%), \beta$-pinene $(5,4 \%)$, @-cymene $(2,1 \%)$ dan terpinolene $(2,0 \%)$. Komponen kimia tersebut telah menunjukkan beberapa potensi biologis seperti antimikroba, insektisida dan sitotoksik [2]. Selain itu, daun kapas juga mengandung senyawa glikosida sianogenik [7].

Hasil uji antibakteri ekstrak metanol daun kapas (Gossypium barbadense L.) memiliki zona hambat terhadap pertumbuhan bakteri Staphylococcus aureus pada konsentrasi $30 \mathrm{mg} / \mathrm{mL}$ sebesar $16 \mathrm{~mm}$ [3]. Bakteri tersebut merupakan salah satu bakteri penyebab jerawat [8]. Berdasarkan potensi antibakteri terhadap bakteri genus Staphylococcus, maka dapat diasumsikan ekstrak daun kapas diduga memiliki potensi antibakteri terhadap bakteri Staphylococcus epidermidis. Telah diketahui bakteri yang umum menginfeksi jerawat adalah Staphylococcus epidermidis, Staphylococcus aureus, dan Propionibacterium acnes $[9,10]$. Bakteri-bakteri penyebab jerawat dapat menghidrolisis lemak yang memecah asam lemak bebas dari lipid kulit sehingga menyebabkan peradangan [11]. Akibat peradangan tersebut menyebabkan bakteri berproliferasi dan memperparah lesi jerawat [12]. Berdasarkan hal tersebut, perlu dilakukan uji aktivitas daun kapas sebagai antibakteri khususnya penyebab jerawat yaitu Staphylococcus epidermidis dan Propionibacterium acnes.

\section{METODE}

Alat

Seperangkat alat ekstraksi, oven $\left(\right.$ Shellab ${ }^{\circledR}$ ), vacum rotary evaporator (EYELA), timbangan digital (ADAM), autoklaf (Hirayama), tabung reaksi (Pyrex ${ }^{\circledR}$ Iwaki), labu ukur $50 \mathrm{~mL}$ (Pyrex ${ }^{\circledR}$ Iwaki), labu ukur10 $\mathrm{mL}$ (Pyrex ${ }^{\circledR}$ Iwaki), vortex (OMNI International), Erlenmeyer (Pyrex) 50,250,500 mL, gelas ukur $100 \mathrm{~mL}$ (IWAKI), gelas kimia $100 \mathrm{~mL}$
(Pyrex), jarum ose, pinset, chamber, lampu spritus, inkubator (Eyela $\left.{ }^{\circledR}\right)$, shaker water bath (Grant), jangka sorong (Tricle Brand), Laminary Air Flow (Stream Line), lampu UV 254nm dan 366nm, micropipet $10 \mu \mathrm{L}-100 \mu \mathrm{L}$ (Socorex) dan pencadang baja (sumuran).

\section{Bahan}

Daun kapas diperoleh dari Desa Dolo, Kecamatan Sigi Biromaru, Kabupaten Sigi, Sulawesi Tengah dan telah diidentifikasi di Laboratorium Biodiversitas Jurusan Biologi FMIPA Universitas Tadulako, isolat bakteri Staphylococcus epidermidis, isolat bakteri Propionibacterium acnes yang diperoleh dari UPT Laboratorium Kesehatan Provinsi Sulawesi Tengah, medium nutrien agar, medium agar darah, akuades, larutan standar 0,5 Mc. Farland I, etanol 96\% (Merck), kloramfenikol 0,1\%, larutan fisiologis $\mathrm{NaCl}$ 0,9\% (Otsuka), Dimetil Sulfoksida (DMSO), lempeng KLT GF 254 (Merck), asam sulfat $\left(\mathrm{H}_{2} \mathrm{SO}_{4}\right) 10 \%$, pereaksi besi (III) klorida $\left(\mathrm{FeCl}_{3}\right)$ $1 \%$, pereaksi anisaldehid-asam sulfat, pereaksi Lieberman-Burchard, pereaksi aluminium klorida $\left(\mathrm{AlCl}_{3}\right)$ 1\%, dan pereaksi Dragendorf.

\section{Ekstraksi Sampel}

Ditimbang sebanyak 140,09 gram serbuk simplisia, dimaserasi dengan 1,5 liter etanol 96\% selama 3 hari dan dilakukan pengadukan setiap harinya. Selanjutnya disaring, filtrat dipekatkan dengan rotary evaporator pada suhu $50^{\circ} \mathrm{C}$ lalu diuapkan sisa pelarutnya dengan oven pada suhu $50^{\circ} \mathrm{C}$ sampai menjadi ekstrak kental.

\section{Pembuatan Suspensi Bakteri Uji}

Sebanyak 2 ose bakteri uji hasil peremajaan, disuspensikan dalam $2 \mathrm{~mL} \mathrm{NaCl}$ fisiologis dalam tabung reaksi steril dan dihomogenkan dengan vortex selama 15 detik, kemudian kekeruhannya dilihat dengan membandingkan kekeruhan standar 0,5 Mc. Farland I (konsentrasi bakteri 1,5 x $10^{8}$ $\mathrm{CFU} / \mathrm{mL}$ ).

\section{Pembuatan Media}

a. Medium Nutrien Agar

Sebanyak 4 gram media Nutrien Agar (NA) dilarutkan dalam $200 \mathrm{~mL}$ akuades steril. Media dipanaskan sampai mendidih. Dilakukan pengadukan dengan menggunakan 
DOI : https://doi.org/10.24843/JFU.2020.v09.i01.p08

pISSN: 2301-7716; eISSN: 2622-4607

Jurnal Farmasi Udayana, Vol 9, No 1, Tahun 2020, 53-62

magnetic stirer untuk memastikan media terlarut sempurna. Setelah media terlarut sempurna, kemudian diautoklaf pada suhu $121^{\circ} \mathrm{C}$ selama 15 menit, lalu ditunggu sampai suhu hangat $\left(40^{\circ} \mathrm{C}-45^{\circ} \mathrm{C}\right)$ [13].

b. Medium Agar Darah

Sebanyak 38 gram Mueller Hinton Agar (MHA) dilarutkan ke dalam $1000 \mathrm{~mL}$ akuades steril dan dipanaskan selanjutnya disterilkan di autoklaf pada suhu $121^{\circ} \mathrm{C}$ selama 15 menit dinginkan media sampai suhu hingga 45$50^{\circ} \mathrm{C}$. Ditambahkan $5 \%$ darah domba segar. Kemudian darah domba segar dituangkan ke dalam labu berisi MHA [14].

\section{Larutan Uji}

Larutan uji dibuat dengan menimbang 225 mg ekstrak kemudian dilarutkan dalam $225 \mu \mathrm{L}$ DMSO. Selanjutnya diencerkan menjadi konsentrasi $70 \%$ sampai $10 \%$ dengan pelarut DMSO.

\section{Pengujian Aktivitas Antibakteri}

Pengujian aktivitas antibakteri dari ekstrak etanol daun kapas terhadap Staphylococcus epidermidis dan Propionibacterium acnes dilakukan dengan menggunakan metode difusi agar teknik sumuran. Medium NA untuk bakteri Staphylococcus epidermidis dan medium agar darah untuk Propionibacterium acnes yang masih berbentuk cairan dituang ke dalam cawan petri steril $\pm 10 \mathrm{~mL}$ dan dibiarkan memadat sebagai lapisan dasar. Setelah agar memadat, ditanam pencadang baja pada permukaan lapisan dasar yang diatur jaraknya agar daerah pengamatan tidak bertumpu. Kemudian suspensi bakteri sebanyak $0,1 \mathrm{~mL}$ diinokulasikan ke dalam media yang masih cair, dihomogenkan dan dituang ke dalam cawan petri sebanyak $20 \mathrm{~mL}$ sebagai lapisan kedua, ditunggu hingga memadat. Selanjutnya pencadang diangkat menggunakan pinset sehingga terbentuk sumur-sumur yang akan digunakan dalam uji bakteri. Variasi konsentrasi larutan uji yang digunakan yaitu 10\%, 20\%, 30\%, $40 \%$ dan 50\% untuk Staphylococcus epidermidis serta $20 \%, 30 \%, 40 \%, 50 \%, 60 \%$ dan $70 \%$ untuk Propionibacterium acnes. Larutan uji dimasukkan ke dalam sumuran yang sudah dibuat sebelumnya sebanyak $50 \mu \mathrm{L}$ menggunakan mikropipet, sehingga diperoleh loading dose (jumlah ekstrak etanol daun kapas dalam setiap $\mu \mathrm{L}$ ) sebesar 0,1 sampai $0,7 \mathrm{mg} / \mu \mathrm{L}$. Pengujian dilakukan 3 kali pengulangan.

Sebagai pembanding digunakan empat macam kontrol yaitu:

a. Kontrol positif $=$ Kloramfenikol 0,1\%

b. Kontrol negatif $=$ DMSO

c. Kontrol media NA dan media Agar Darah

d. Kontrol bakteri Staphylococcus epidermidis dan Propionibacterium acnes

\section{KLT Bioautografi}

Suspensi bakteri Staphylococcus epidermidis dan Propionibacterium acnes sebanyak 0,1 $\mathrm{mL}$ diinokulasikan pada $20 \mathrm{~mL}$ media agar darah dan media NA steril di dalam cawan petri yang dilakukan secara aseptik. Media agar dibiarkan memadat, kemudian lempeng KLT yang telah dielusi dengan eluen, diuapanginkan dan selanjutnya diletakkan di atas permukaan media agar yang sudah padat. Lempeng kemudian dibiarkan berdifusi selama 30 menit, selanjutnya lempeng tersebut dipindahkan. Cawan petri kemudian diinkubasi pada suhu $37^{\circ} \mathrm{C}$ selama 24 jam dalam kondisi aerob untuk Staphylococcus epidermidis sedangkan untuk Propionibacterium acnes pada suhu $37^{\circ} \mathrm{C}$ selama 72 jam dalam kondisi anaerob. Zona hambat yang terlihat pada media agar dibandingkan dengan hasil pengamatan lempeng KLT pada sinar tampak dan dibawah lampu UV (254 dan $366 \mathrm{~nm}$ ) serta pereaksi penampak noda $[15,16]$.

\section{HASIL}

Hasil maserasi serbuk simplisia daun kapas menggunakan pelarut etanol 96\% menghasilkan rendemen sebesar 3,51\%. Hasil ini lebih rendah jika dibandingkan yang telah dilakukan oleh Hasniar dkk (2015) yang menghasilkan rendemen 11,57\% [17]. Hal ini dapat terjadi karena adanya perbedaan tempat tumbuh dari sampel yang digunakan, sehingga mengakibatkan perbedaan dari banyaknya kandungan senyawa yang dihasilkan. Tempat tumbuh dapat mempengaruhi kondisi curah hujan, ketinggian wilayah dan sinar matahari sehingga akan mempengaruhi fotosintesis tanaman $[18,19]$. 


\section{Nugrahani dkk.}

DOI : https://doi.org/10.24843/JFU.2020.v09.i01.p08

pISSN: 2301-7716; eISSN: 2622-4607

Jurnal Farmasi Udayana, Vol 9, No 1, Tahun 2020, 53-62

Tabel 1. Hasil pengujian aktivitas antibakteri ekstrak etanol daun kapas terhadap bakteri Staphylococcus epidermidis

\begin{tabular}{|c|c|c|c|c|c|c|}
\hline \multirow{3}{*}{ Sampel Uji } & \multirow{3}{*}{$\begin{array}{c}\text { Konsentrasi } \\
(\%)\end{array}$} & \multirow{3}{*}{$\begin{array}{c}\text { Loading } \\
\text { dose } \\
(\mathrm{mg} / \mu \mathrm{L})\end{array}$} & \multirow{2}{*}{\multicolumn{3}{|c|}{$\begin{array}{c}\begin{array}{c}\text { Zona hambat } \\
(\mathrm{mm})\end{array} \\
\text { Replikasi }\end{array}$}} & \multirow{3}{*}{$\begin{array}{c}\text { Rata-rata zona hambat } \\
(\mathrm{mm}) \pm \mathrm{SD}\end{array}$} \\
\hline & & & & & & \\
\hline & & & 1 & 2 & 3 & \\
\hline \multirow[t]{5}{*}{ Ekstrak Etanol } & 10 & 0,1 & 8,28 & 8,91 & 9,10 & $8,76 \pm 0,42$ \\
\hline & 20 & 0,2 & 8,90 & 9,12 & 9,78 & $9,26 \pm 0,45$ \\
\hline & 30 & 0,3 & 9,62 & 9,71 & 11,10 & $10,14 \pm 0,82$ \\
\hline & 40 & 0,4 & 10,40 & 10,40 & 11,90 & $10,90 \pm 0,86$ \\
\hline & 50 & 0,5 & 11,91 & 11,73 & 12,90 & $12,28 \pm 0,63$ \\
\hline Kontrol Negatif & 0 & 0 & 0,00 & 0,00 & 0,00 & $0,00 \pm 0,00$ \\
\hline Kontrol Positif & 0,1 & 0,001 & & 21,9 & & \\
\hline Kontrol Media & \multicolumn{6}{|c|}{ Steril } \\
\hline Kontrol Bakteri & \multicolumn{6}{|c|}{ Positif } \\
\hline
\end{tabular}

Tabel 2. Hasil pengujian aktivitas antibakteri ekstrak etanol daun kapas terhadap bakteri Propionibacterium acnes

\begin{tabular}{|c|c|c|c|c|c|c|}
\hline \multirow[t]{3}{*}{ Sampel Uji } & \multirow{3}{*}{$\begin{array}{c}\text { Konsentrasi } \\
(\%)\end{array}$} & \multirow{3}{*}{$\begin{array}{c}\text { Loading } \\
\text { dose } \\
(\mathrm{mg} / \mu \mathrm{L})\end{array}$} & \multicolumn{3}{|c|}{$\begin{array}{c}\text { Zona hambat } \\
\text { (mm) }\end{array}$} & \multirow{3}{*}{$\begin{array}{c}\text { Rata-rata zona } \\
\text { hambat } \\
(\mathrm{mm}) \pm \mathrm{SD}\end{array}$} \\
\hline & & & \multicolumn{3}{|c|}{ Replikasi } & \\
\hline & & & 1 & 2 & 3 & \\
\hline \multirow[t]{6}{*}{ Ekstrak Etanol } & 20 & 0,2 & 7,54 & 7,17 & 8,10 & $7,60 \pm 0,46$ \\
\hline & 30 & 0,3 & 8,16 & 8,48 & 9.01 & $8,32 \pm 0,22$ \\
\hline & 40 & 0,4 & 9,37 & 9,76 & 9,90 & $9,67 \pm 0,27$ \\
\hline & 50 & 0,5 & 9,97 & 10,10 & 10,36 & $10,14 \pm 0,19$ \\
\hline & 60 & 0,6 & 10,20 & 10,79 & 10,91 & $10,63 \pm 0,38$ \\
\hline & 70 & 0,7 & 11,53 & 11,04 & 11,65 & $11,40 \pm 0,32$ \\
\hline Kontrol Negatif & 0 & 0 & 0,00 & 0,00 & 0,00 & $0,00 \pm 0,00$ \\
\hline Kontrol Positif & 0,1 & 0,001 & & 23,8 & & \\
\hline Kontrol Media & \multicolumn{6}{|c|}{ Steril } \\
\hline Kontrol Bakteri & & & & & & \\
\hline
\end{tabular}

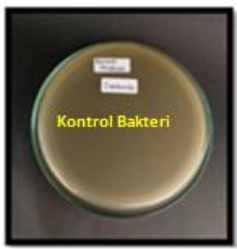

a

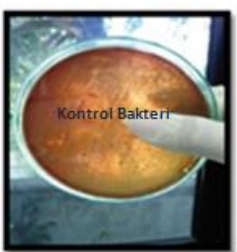

a

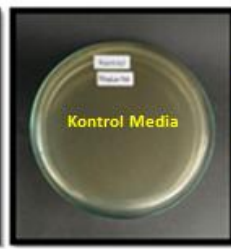

b

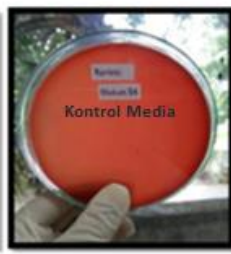

$\mathrm{b}$

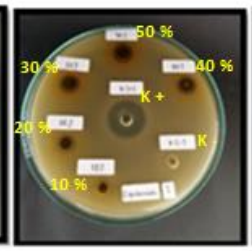

c

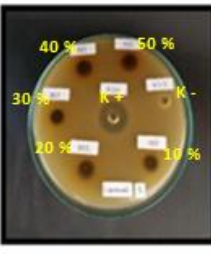

d

(A)

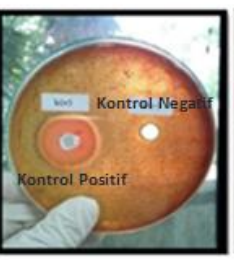

(B)

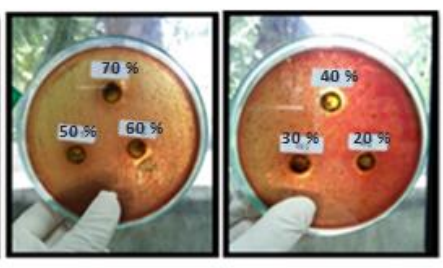

e (a: Kontrol bakteri; b: Kontrol media; c,d dan e: Perlakuan) (A) Bakteri Staphylococcus epidermidis (B) Bakteri Propionibacterium acnes

Gambar 1. Pengamatan zona hambat 
Nugrahani dkk.

DOI : https://doi.org/10.24843/JFU.2020.v09.i01.p08

pISSN: 2301-7716; eISSN: 2622-4607

Jurnal Farmasi Udayana, Vol 9, No 1, Tahun 2020, 53-62

Tabel 3. Hasil Identifikasi dengan Pereaksi Semprot pada Lempeng KLT

\begin{tabular}{|c|c|c|c|c|}
\hline \multirow{2}{*}{ Pereaksi } & \multirow{2}{*}{ Nilai Rf } & \multicolumn{3}{|c|}{ Warna Noda } \\
\hline & & UV $254 \mathrm{~nm}$ & UV $366 \mathrm{~nm}$ & Penampak noda \\
\hline \multirow{3}{*}{ Anisaldehid-asam sulfat } & 0,41 & - & Ungu & - \\
\hline & 0,68 & - & Ungu & - \\
\hline & 0,85 & - & Biru & - \\
\hline \multirow{3}{*}{ Asam sulfat $10 \%$} & 0,41 & - & Ungu & - \\
\hline & 0,67 & - & Ungu & - \\
\hline & 0,85 & - & Biru & - \\
\hline \multirow{3}{*}{ Feri klorida $1 \%$} & 0,48 & - & Ungu & - \\
\hline & 0,74 & - & Biru & - \\
\hline & 0,85 & Hitam & Ungu & Biru kehitaman \\
\hline \multirow{3}{*}{ Liebermann-Burchard } & 0,38 & - & Ungu & - \\
\hline & 0,61 & - & Ungu & - \\
\hline & 0,78 & - & Biru & - \\
\hline \multirow{3}{*}{$\begin{array}{c}\text { Aluminium triklorida } 1 \\
\%\end{array}$} & 0,51 & - & Ungu & - \\
\hline & 0,78 & - & Biru & - \\
\hline & 0,85 & Hitam & Ungu & Kuning \\
\hline \multirow{3}{*}{ Dragendorff } & 0,40 & - & Ungu & - \\
\hline & 0,64 & - & Ungu & - \\
\hline & 0,84 & - & Biru & - \\
\hline
\end{tabular}

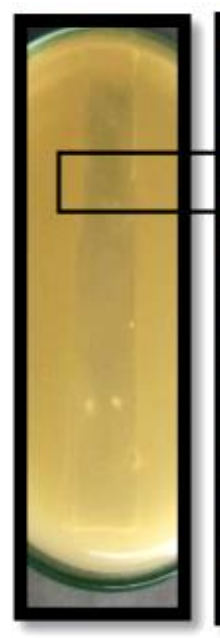

(a)

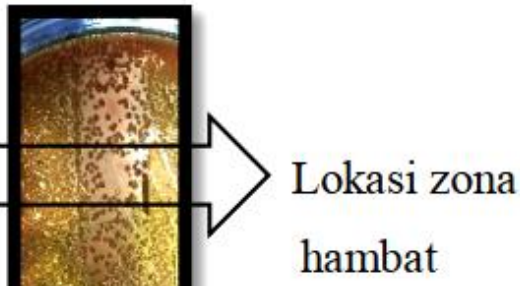

(a) Bakteri Staphylococcus epidermidis

(b) Bakteri Propionibacterium acnes

Gambar 2. Hasil KLT Bioautografi 
DOI : https://doi.org/10.24843/JFU.2020.v09.i01.p08

pISSN: 2301-7716; eISSN: 2622-4607

Jurnal Farmasi Udayana, Vol 9, No 1, Tahun 2020, 53-62

\section{PEMBAHASAN}

Hasil pengukuran diameter zona hambat terhadap pengujian aktivitas antibakteri ekstrak etanol daun kapas dengan konsentrasi 10\%, 20\%, $30 \%, \quad 40 \%$ dan $50 \%$ terhadap bakteri uji Staphylococcus epidermidis dan Propionibacterium acnes dengan konsentrasi $20 \%, 30 \%, 40 \%, 50 \%, 60 \%$ dan $70 \%$ dapat dilihat pada tabel 1 , tabel 2 dan gambar 1.

Pemanfaatan daun kapas (Gossypium barbadense L.) sebagai antibakteri khususnya terhadap bakteri Staphylococcus epidermidis dan Propionibacterium acnes, dapat diidentifikasi dengan cara melakukan pengujian aktivitas antibakteri ekstrak daun kapas yang ditandai dengan adanya zona hambat pada media uji kedua bakteri. Ekstrak hasil maserasi dibuat variasi konsentrasi dalam pengujian aktivitas antibakteri yang bertujuan untuk mengetahui pengaruh konsentrasi terhadap aktivitas antibakteri dari ekstrak etanol daun kapas dalam menghambat pertumbuhan bakteri Staphylococcus epidermidis dan Propionibacterium acnes.

Perbedaan medium yang digunakan pada kedua bakteri tersebut didasarkan pada perbedaan kebutuhan nutrisi dan sifat fisiologi dari kedua bakteri. Terakumulasinya sebum oleh adanya kelebihan sekresi dan hiperkeratosis pada infundibulum rambut menjadi sumber nutrisi yang baik bagi pertumbuhan Propionibacterium acnes. Enzim lipase yang dihasilkan dari bakteri tersebut menguraikan trigliserida pada sebum menjadi asam lemak bebas yang menyebabkan inflamasi dan akhirnya terbentuk jerawat [20]. Berdasarkan hal tersebut, bakteri Propionibacterium acnes tidak hanya memerlukan media yang mengandung komponen dasar untuk pertumbuhan tetapi ditambah komponen kompleks seperti darah. Hal ini dipengaruhi oleh sifat Propionibacterium acnes yang kemoatraktan yaitu menarik komponen leukosit dalam darah [21], sedangkan Staphylococcus epidermidis menginfeksi di bagian permukaan kulit sehingga tidak memerlukan komponen tambahan pada media yang digunakan. Selanjutnya, metode difusi agar dipilih untuk memudahkan proses kontak antara senyawa antibakteri dengan bakteri uji. Hal tersebut dikarenakan komponen terbesar dari media pertumbuhan bakteri adalah air sehingga proses difusi senyawa antibakteri dapat berlangsung lebih mudah dan lebih merata ke seluruh bagian media [22,23].

Hasil pengukuran zona hambat pada tabel 1 dan 2 menunjukkan bahwa semakin tinggi konsentrasi ekstrak etanol daun kapas maka semakin besar pula zona hambat yang diberikan. Bakteri uji Staphylococcus epidermidis berhasil dihambat oleh ekstrak etanol daun kapas pada konsentrasi $10 \%(8,76 \mathrm{~mm})$ sedangkan bakteri Propionibacterium acnes pada konsentrasi 20\% (7,60 $\mathrm{mm})$. Konsentrasi ekstrak etanol daun kapas 10\% untuk Propionibacterium acnes tidak digunakan dalam seri konsentrasi karena pada saat orientasi tidak memberikan aktivitas antibakteri $(0,00 \mathrm{~mm})$. Perbedaan konsentrasi terendah dalam menghambat kedua bakteri tersebut dikarenakan faktor sensitivitas dan respon sel bakteri uji terhadap senyawa antibakteri dalam ekstrak etanol daun kapas [24]. Selain itu, kemungkinan juga dapat dipengaruhi oleh pertumbuhan bakteri Propionibacterium acnes yang membutuhkan waktu lebih lama dibandingkan Staphylococcus epidermidis sehingga membutuhkan konsentrasi ekstrak etanol daun kapas yang lebih tinggi untuk dapat menghambatnya.

Berdasarkan hasil pengujian, diketahui bahwa konsentrasi 50\% ekstrak etanol daun kapas terhadap Staphylococcus epidermidis dan konsentrasi 70\% terhadap Propionibacterium acnes memiliki zona hambat terbesar untuk masing-masing bakteri uji. Hasil ini menunjukkan bahwa konsentrasikonsentrasi tersebut memiliki aktivitas terbaik untuk setiap bakteri uji yang termasuk dalam kategori sedang [25]. Hal ini juga menggambarkan efektivitas senyawa yang terkandung dalam ekstrak etanol daun kapas.

Kontrol positif dan negatif tidak dilakukan replikasi karena fungsinya hanya sebagai penanda terhadap zona hambat yang sebenarnya dan tidak sebagai pembanding. Kontrol bakteri digunakan sebagai penanda bahwa media yang digunakan dalam pengujian itu fertile yang artinya mampu menumbuhkan bakteri uji sedangkan kontrol media sebagai penanda bahwa media uji steril atau terbebas dari kontaminan. Berdasarkan pengamatan, kontrol positif memberikan aktivitas antibakteri berupa zona bening di sekitar sumuran. 
DOI : https://doi.org/10.24843/JFU.2020.v09.i01.p08

pISSN: 2301-7716; eISSN: 2622-4607

Jurnal Farmasi Udayana, Vol 9, No 1, Tahun 2020, 53-62

Kontrol negatif berupa DMSO tidak memberikan aktivitas antibakteri. Kontrol bakteri dinyatakan fertile karena media ditumbuhi oleh bakteri uji secara merata dan media sebagai kontrol dinyatakan steril ditandai dengan tidak adanya pertumbuhan bakteri di dalamnya.

\section{KLT Bioautografi}

Pengujian KLT bioautografi untuk menemukan suatu senyawa antibakteri yang belum teridentifikasi dengan cara melokalisir aktivitas antibakteri tersebut pada suatu kromatogram. Tahapan yang dilakukan ialah ekstrak etanol daun kapas dilarutkan dengan kloroform : metanol (1:1) lalu ditotolkan pada lempeng KLT, kemudian dielusi menggunakan etil asetat : butanol $(7: 2)$ sampai batas atas lempeng KLT. Pemilihan perbandingan eluen tersebut memberikan pemisahan terbaik. Hal tersebut dapat dilihat dengan adanya noda yang terpisah dengan baik. Kemudian dibiarkan beberapa saat untuk menghilangkan pelarutnya dan dikontakkan di permukaan medium padat berisikan masingmasing inokulum Staphylococcus epidermidis dan Propionibacterium acnes. Lempeng diangkat dan media diinkubasi selama 1x24 jam. Pengamatan dilakukan dengan melihat permukaan media yang membentuk zona yang jernih.

Hasil KLT bioautografi pada ekstrak etanol daun kapas menunjukkan aktivitas antibakteri yang terlokalisir pada kromatogram ditandai dengan adanya zona hambat pada permukaan media yang terlihat seperti gambar 2 .

\section{Identifikasi dengan Pereaksi Semprot pada Lempeng KLT}

Hasil identifikasi golongan senyawa dapat dilihat pada tabel 3. Noda yang memberikan penghambatan pada kedua kultur bakteri selanjutnya diidentifikasi menggunakan pereaksi penampak noda yaitu pereaksi anisaldehid-asam sulfat, pereaksi $\mathrm{H}_{2} \mathrm{SO}_{4} 10 \%$, pereaksi feri klorida $1 \%$, pereaksi Liebermann-Burchard, pereaksi aluminium klorida 1\%, dan pereaksi Dragendorff. Tujuan identifikasi dengan menyemprotkan pereaksi pada plat KLT adalah untuk mengetahui golongan senyawa kimia yang diduga berperan dalam memberikan aktivitas antibakteri dari uji
KLT bioautografi. Berdasarkan hasil identifikasi, senyawa yang diduga memberikan aktivitas penghambatan adalah senyawa golongan flavonoid. Hal ini dikarenakan pada hasil visualisasi noda pada plat KLT setelah disemprotkan dengan pereaksi aluminium klorida menghasilkan noda yang berwarna kuning [26] dan dengan pereaksi feri klorida berwarna biru kehitaman [27]. Senyawa flavonoid adalah bagian dari kelompok senyawa fenolik, sehingga memberikan hasil yang positif dengan pereaksi feri klorida. Mekanisme kerja flavonoid sebagai antibakteri diduga melalui penghambatan fungsi membran sitoplasma dalam hal ini seperti yang ditunjukkan oleh galangin yang dapat menyebabkan peningkatan yang nyata pada kehilangan kalium dari sel $S$. aureus, yang mengindikasikan kerusakan langsung pada membran sitoplasma dari dinding sel $S$. aureus [28]. Selain itu juga dapat melalui penghambatan sintesis asam nukleat bakteri. Hal ini seperti yang telah ditunjukkan oleh aktivitas genistein [29]. Selanjutnya, flavonoid dapat menghambat pertumbuhan bakteri melalui penghambatan metabolisme energi, misalnya apigenin dan naringenin mengubah membran luar dan sitoplasma sel E.cloacae, akibatnya mengganggu pertukaran nutrisi dan metabolit dan akhirnya menghambat pasokan energi untuk bakteri [30]. Dalam ulasan lain, hambatan sintesis membran sel dan efek agregat secara keseluruhan sel-sel bakteri juga telah dianggap sebagai mekanisme yang mungkin dari aktivitas antibakteri flavonoid $[31,32]$.

\section{KESIMPULAN}

Ekstrak etanol daun kapas (Gossypium barbadense L.) pada konsentrasi 50\% memberikan daya hambat terbesar terhadap bakteri Staphylococcus epidermidis sebesar 12,28 $\pm 0,63 \mathrm{~mm}$ dan konsentrasi $70 \%$ memiliki daya hambat terbesar yaitu $11,40 \pm 0,32 \mathrm{~mm}$ terhadap Propionibacterium acnes. Senyawa aktif yang diduga menghambat pertumbuhan kedua bakteri tersebut yaitu senyawa golongan flavonoid.

\section{UCAPAN TERIMA KASIH}

Terima kasih diucapkan kepada Bapak Moh. Iqbal, M.Sc., dan Bapak Sahlan, S.Si., dari 
DOI : https://doi.org/10.24843/JFU.2020.v09.i01.p08

pISSN: 2301-7716; eISSN: 2622-4607

Jurnal Farmasi Udayana, Vol 9, No 1, Tahun 2020, 53-62

Laboratorium Biodiversitas Jurusan Biologi FMIPA Universitas Tadulako yang telah membantu mengidentifikasi tumbuhan yang digunakan pada penelitian ini.

\section{DAFTAR RUJUKAN}

1. Al-Fatimi M, Wurster M, Schroder G, \& Lindequist U. Antioxidant, antimicrobialand cytotoxic activity of selected medicinal plants from Yemen. Journal of Ethnopharmacology. 2007. 111(3):657-666. https://doi.org/10.1016/j.jep.2007.01.018.

2. Essien EE, Aboaba SO, Isiaka A, Ogunwande IA. Constituents and antimicrobial properties of the leaf essential oil of Gossypium barbadense (Linn.) Journal of Medicinal Plants Research. 2011. 5(5):702-705.

https://academicjournals.org/ article/article1380619736 Essien \%20et \%20a $\underline{\text { l.pdf. }}$.

3. Ikobi E, Igwilo CI, Awodele O, Azubuike C. Antibacterial and wound healing properties of methanolic extract of dried fresh Gossypium barbadense Leaves. Asian Journal of Biomedical and Pharmaceutical Science. 2012. 2(13):3237.

https://www.alliedacademies.org/articles/an tibacterial-and-wound-healing-properties-ofmethanolic-extract-of-dried-fresh-gossypiumbarbadense-leaves.pdf.

4. Saidu TB, Abdullahi M. Phytochemical determinations and antibacterial activities of the leaf extracts of Combretum molle and Gossypium arboreum, Bayero Journal of Pure and Applied Sciences. 2011.4(2):132 $136 . \quad$ http://dx.doi.org/10.4314/ bajopas.v4i2.26.

5. Annan K, Houghton PJ. Antibacterial, antioxidant and fibroblast growth stimulation of aqueous extracts of Ficus asperifolia Miq. and Gossypium arboreum L., wound-healing plants of Ghana. Journal of Ethnopharmacology. 2008. 119(1):141-144. https://doi.org/10.1016/j.jep.2008.06.017.

6. Ade-Ademilua OE, \& Okpoma MO. Gossypium birsutum L. and Gossypium barbadense L.: differences in phytochemical contents, antioxidant and antimicrobial properties. Ife
Journal of Science. 2018. 20(1):077-088. https://doi.org/10.4314/ijs.v20i1.8.

7. Muhammad Z, Masanawa AA, \& Pyeng AK. Phytochemical and mineral analysis of methanolic extract of Gossypium barbadense L. (Cotton leaves). Annals of Experimental Biology. 2014. 2(4):11-15. https://www.scholarsresearchlibrary.com/ articles/phytochemical-and-mineral-analysisof-methanolic-extract-of-gossypium-

barbadense-l-cotton-leaves.pdf.

8. Kumar B, Pathak R, Mary PB, Jha D, Sardana $K$, \& Gautam HK. New insights into acne pathogenesis: exploring the role of acneassociated microbial populations, Dermatologica Sinica. 2016. 34(2): 67-73. https://doi.org/10.1016/j.dsi.2015. 12.004.

9. Dhillon KS \& Varshney KR. Study of microbiological spectrum in acne vulgaris: an in vitro study. Scholars Journal of Applied Medical Sciences. 2013. 1(6):724-727. http://saspublisher.com/wpcontent/uploads/2013/12/SJAMS16724727.pdf.

10. Katsambas A, \& Dessinioti C. New and emerging treatments in dermatology: acne. Dermatologic Therapy. 2008. 21(2): 86-95. https://doi.org/10.1111/j.1529-8019. 2008.00175.x.

11. Prasad SB. Acne vulgaris: a review on pathophysiology and treatment. Asian Journal of Pharmaceutical Clinical Research. 2016. 9(4):54-59. https://innovare academics.in/journals/index.php/ajpcr/artic le/view/12866.

12. Fabbrocini $G$, Annunziata MC, D'arco V, De vita V, Lodi G, Mauriello MC, et al. Review article acne scars: pathogenesis, classification and treatment. Dermatology Research and Practice. 2010:1-13. https://doi.org/10.1155/2010/893080.

13. Ngajow M, Abidjulu J, Kamu VS. Pengaruh antibakteri ekstrak kulit batang matoa (Pometia pinnata) terhadap bakteri Staphylococcus aureus secara in vitro. Jurnal Mipa Unsrat Online. 2013. 2(2):128-132. https://ejournal.unsrat.ac.id/index.php/ imuo/article/view/3121/2665. 
DOI : https://doi.org/10.24843/JFU.2020.v09.i01.p08

pISSN: 2301-7716; eISSN: 2622-4607

Jurnal Farmasi Udayana, Vol 9, No 1, Tahun 2020, 53-62

14. Murtiningsih S, Nurbaeti SN, Kusharyanti I. Efektivitas gel antijerawat ekstrak metanol daun pacar air (Impatiens balsamina L.) terhadap bakteri Propionibacterium acnes dan Staphylococcus epidermidis secara in vitro. Journal of Tropical Pharmacy and Chemistry. 2014. 2(4):225-234. https://doi.org/10.25026/ itpc.v2i4.68.

15. Dewanjee S, Gangopadhyay M, Bhattacharya N, Khanra R, \& Dua TK. Bioautography and its scope in the field of natural product chemistry. Journal of Pharmaceutical Analysis. 2015. $5(2): 75-84$. http://dx.doi.org/10.1016/i.jpha.2014. 06.002 .

16. Choma IM, \& Jesionek W. TLC-direct bioautography as a high throughput method for detection of antimicrobials in plants. Chromatography. 2015. 2:225-238. doi:10.3390/chromatography2020225.

17. Hasniar, Yusriadi, \& Khumaidi A. Formulasi krim antioksidan ekstrak daun kapas (Gossypium sp.). Jurnal Farmasi Galenika (Galenika Journal of Pharmacy). 2015.1(1):915.

https://doi.org/10.22487/j24428744.2015.v 1.i1.4830.

18. Astuti E, Sunarminingsih R, Jenie UA, Mubarika $S$ \& Sismindari. Impact of growing sites, plant ages and variance of distillation types to Curcuma mangga essential oil composition of several areas production in Yogyakarta. Jurnal Manusia dan Lingkungan. 2014.

21(3):323-330. https://doi.org/10.22146/jml. 18560.

19. Lallo S, Lewerissa AC, Rafi'i A,Usmar, Ismail, Tayeb R. Pengaruh ketinggian tempat tumbuh terhadap aktivitas antioksidan dan sitotoksik ekstrak rimpang lengkuas (Alpinia galanga L.). Majalah Farmasi dan Farmakologi. 2019. 23(3):118-123.

http://journal.unhas.ac.id/index.php/mff/ar ticle/view/9406/4802.

20. Dréno B, Pécastaings S, Corvec S, Veraldi S, Khammari A, Roque C. Cutibacterium acnes (Propionibacterium acnes) and acne vulgaris: a brief look at the latest updates. Journal of the European Academy of Dermatology and
Venereology,

2018 https://doi.org/10.1111/idv.15043.

21. Capoor MN, Ruzicka F, Sandhu G, Rollason $\mathrm{J}$, Mavrommatis $\mathrm{K}$, Ahmed FS, et al. Importance of Propionibacterium acnes hemolytic activity in human intervertebral discs: A microbiological study. PLoS One. 2018. 13(11):1-10. https://dx.doi. org/10.1371\%2Fjournal.pone.0208144.

22. Balouiri M, Sadiki M, Ibnsouda SK. Methods for in vitro evaluating antimicrobial activity: A review. Journal of Pharmaceutical Analysis. 2016. 6(2):71-79. https://doi.org/10.1016/i.jpha.2015.11.005.

23. Atlas RM. Handbook of Microbiological Media Fourth Edition. Boca Raton: CRC press Taylor \& Francis Group. 2010.

24. Nester EW. Microbiology a human perspective $3^{\text {rd }}$ Edition. New York: Mc Graw Hill. 2001.

25. Johnson, T. and C, Case. Chemical Methods of Control, adapted from Laboratory Experiments in Microbiology, Brief Edition, 4th ed. Redwood City, CA: Benjamin/Cummings Publishing Co., 1995. available online from The National Health Museum, http://www.accessexcellence.org/AE/AEC $\angle \mathrm{CC} /$ chance activity. html, [accessed March 22, 2020].

26. Pękal A, \& Pyrzynska K. Evaluation of aluminium complexation reaction for flavonoid content assay. Food Analytical Methods. 2014.7(9):1776-1782. doi 10.1007/s12161-014-9814-x.

27. Ahmad AR, Juwita, Ratulangi SAD, Malik A. Penetapan kadar fenolik dan flavonoid total ekstrak metanol buah dan daun patikala (Etlingera elatior (Jack) R.M.SM). Pharmaceutical Sciences and Research (PSR). 2015. 2(1):1-10. http://dx.doi.org/10.7454/psr.v2i1.3481.

28. Cushnie TPT, Lamb AJ. Detection of galangin-induced cytoplasmic membrane damage in Staphylococcus aureus by measuring potassium loss. Journal of Ethnopharmacology. 2005. 101(1-3): 243- 
Nugrahani dkk.

DOI : https://doi.org/10.24843/JFU.2020.v09.i01.p08

pISSN: 2301-7716; eISSN: 2622-4607

Jurnal Farmasi Udayana, Vol 9, No 1, Tahun 2020, 53-62

248. $\quad$ https://doi.org/10.1016/i.jep.2005. 04.014.

29. Ulanowska K, Tkaczyk A, Konopa G, \& Wegrzyn G. Differential antibacterial activity of genistein arising from global inhibition of DNA, RNA and protein synthesis in some bacterial strains. Archives of Microbiology. 2006. 184(5):271-278. https://doi.org/10.1007/s00203-005-0063-7.

30. Eumkeb G, Chukrathok S. Synergistic activity and mechanism of action of ceftazidime and apigenin combination against ceftazidimeresistant Enterobacter cloacae. Phytomedicine: International Journal of Phytotherapy and Phytopharmacology. 2013. 20(3-4):262-269. https://doi.org/10.1016/j.phymed. 2012.10.008.

31. Cushnie TPT, Lamb AJ. Recent advances in understanding the antibacterial properties of flavonoids. International Journal of Antimicrobial Agents. 2011. 38(2):99-107. https://doi.org/10.1016/j.ijantimicag.2011.0 2.014.

32. Xie Y, Yang W, Tang F, Chen X, \& Ren L. antibacterial activities of flavonoids: structureactivity relationship and mechanism. Current Medicinal Chemistry. 2015. 22(1):132-149. https://doi.org/10.2174/0929867321666140 $\underline{916113443}$. 